\section{UCDNN}

LIBRARY
University of Connecticut OpenCommons@UConn

Faculty Articles and Papers

School of Law

1968

\title{
Tax Collection from Estates of Nonresidents
}

Robert Whitman

University of Connecticut School of Law

Follow this and additional works at: https://opencommons.uconn.edu/law_papers

Part of the Estates and Trusts Commons, Taxation-Federal Estate and Gift Commons, and the Taxation-Transnational Commons

\section{Recommended Citation}

Whitman, Robert, "Tax Collection from Estates of Nonresidents" (1968). Faculty Articles and Papers. 294.

https://opencommons.uconn.edu/law_papers/294 


\section{HEINONLINE}

Citation: 68 Colum. L. Rev. 10491968

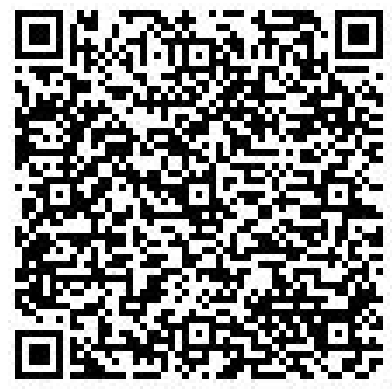

Content downloaded/printed from

HeinOnline (http://heinonline.org)

Mon Aug 15 17:34:37 2016

-- Your use of this HeinOnline PDF indicates your acceptance of HeinOnline's Terms and Conditions of the license agreement available at http://heinonline.org/HOL/License

-- The search text of this PDF is generated from uncorrected OCR text.

-- To obtain permission to use this article beyond the scope of your HeinOnline license, please use:

https://www.copyright.com/ccc/basicSearch.do? \&operation $=$ go\&search Type $=0$ \&lastSearch $=$ simple\&all $=$ on\&titleOrStdNo $=0010-1958$ 


\title{
TAX COLLECTION FROM ESTATES OF NONRESIDENTS
}

\author{
ROBERT WHITMAN*
}

All Americans and many aliens are subject to United States taxes. ${ }^{x}$ Congressional power to impose tax is premised on the benefits this country renders a taxpayer. Taxing power is not measured, and taxes are not imposed, with regard to the power of the Internal Revenue Service, working through its overseas arm, the Office of International Operations (OIO), ${ }^{2}$ to collect tax. Under the Expatriation Act, ${ }^{3}$ Congress recently extended the incidence of United States taxation to individuals who have renounced their citizenship in order to escape taxation. However, no accompanying legislation was proposed in order to assist OIO in the collection of the tax from such persons, who typically have withdrawn virtually all of their assets from this country.

Although we say a tax is owing, there are limitations on OIO collection activities abroad and United States courts may lack the jurisdiction to reach a foreign delinquent taxpayer. Unless OIO is clearly aware of the distinction between the right to impose a tax and the right to collect it; collection procedures and litigation practices will not be carefully thought out, balanced and controlled, and an all-out attempt at aggressive collection by OIO can be expected in every case. If OIO is unable to react properly to the unique problems which foreigners face, the United States cannot expect its citizens to receive better treatment abroad and international cooperation in tax collection will suffer as a result.

The tax collection problems faced by OIO when it is dealing with a nonresident without assets in the United States are due in large part to the inter-

\# Associate Professor of Law, The University of Connecticut School of Law. In connection with the preparation of this article, the author has engaged in informal conversations and correspondence with nembers of the Internal Revenue Service, counsel for several New York banks, and Canadian attorneys. Copies of correspondence and notes on oral conversations have been placed on file with the library of The University of Connecticut School of Law. Professor M. Carr Ferguson, New York University Law School, has reviewed drafts of this work and provided the author with many valuable comments and suggestions.

For a recent survey of the field of international tax evasion published after the completion of this article, see Note, Transnational Tax Evasion of United States Taxation, 81 HARV. L. REv. 876 (1968).

1. Both citizenship and residence are touchstones for application of the federal tax law. In general, all citizens and resident aliens are subject to tax. Treas. Reg. \& 1.1-1 (b) (1956). So long as citizenship is maintained, tax cannot be avoided by absence from the United States for long periods of time, lack of activity within this country, or a withdrawal of all domestic assets.

2. On the development, organization and duties of OIO, see Fox, Office of International Operations: What It Does and How It Functions, 22 J. TAX. 162 (1965).

3. INT. REv. CoDE of $1954, \S \S 877,2107$. On the need for intentional and voluntary renunciation of citizenship in order to bring about expatriation, see Afroyim v. Rusk, 387 U.S. 253 (1967); Schneider v. Rusk, 377 U.S. 163 (1964). For a discussion of the meaning of the term "citizenship" for the purpose of applying the federal estate tax, see 1 G. Merten, Law of Federal Gift and Estate Taxation \& 3.09 (1959). 
nationally accepted rule of law-adhered to by the United States-that the courts of one country will not enforce the revenue laws or claims of another. ${ }^{4}$ This rule remains largely unaffected by a small number of rarely used ${ }^{5}$ reciprocal tax treaty provisions providing for mutual tax collection assistance abroad. ${ }^{6}$ In absence of treaty relief, a nonresident with no assets and no contacts in the United States is beyond the control of OIO, and he may with impunity refuse to pay taxes which Congress has declared to be owing. Given such a situation there is no need to examine the propriety of OIO's collection procedures or the jurisdiction of United States courts; the simple fact is that since tax judgments are not enforceable abroad, collection from the delinquent taxpayer will not be possible.

However, when the taxpayer dies a fiduciary will be appointed to administer his estate. If the fiduciary can be reached, it becomes meaningful to consider the collection procedures available to OIO and the jurisdiction of our

4. United States v. Harden, 41 D.L.R.2d 721 (Can. 1963), noted in 77 Hanv. L. REv. 1327 (1964).

5. Sce 77 Harv. L. Rev. 1327, 1330 (1964). See also Eichel, Admitistrative Aspects of the Pervention and Control of International Tax Evasion, 20 U. MIANI L. REv. 25, 54 (1965); Newman, Tax Administration in Striped Trouscrs: The International Operations Program of the Internal Revente Service, 12 TAx L. Rev. 171, 208 (1957).

6 . Sce Newman, supra note 5, at 205-08. Tax treaties are negotiated through the State Department by the International Tax Relations Division and by the Treasury Department. There are presently twenty-two tax treaties in force. Treaties are entered into primarily to relieve taxpayers of the burden of double taxation. However, an important by-product of the treaties is the provision for exchange of information. Scc Surrey, International Tas Convcntions: How They Operate and What They Accomplish, 23 J. TAx. 364, 366 (1965).

The United States has four tax treaties in force with foreign countries (Denmark, France, Netherlands, and Sweden) containing general provisions for mutual assistance in collection of taxes. Under these treaties if a final determination of a foreign taxpayer's liability is made in the United States, application can be made to the country in which the delinquent taxpayer is residing to have that country collect the tax under its normal collection procedures. Similarly, that country can solicit aid in the United States in order to collect taxes due to it from residents of the United States.

The collection provisions in the treaties with Denmark, France and the Netherlands are limited in that the country requesting assistance will not receive help from the country in which the taxpayer resides if the taxpayer is a citizen of the country in which he resides. The treaty with Sweden is more limited in that the country requesting assistance can only seek assistance in collecting taxes owed to it by its own citizens residing abroad.

The treaty restrictions might present a barrier to the collection of taxes owed by a deceased American citizen who had resided abroad if the decedent's executor is a national of the foreign country in which the decedent had resided. Presumably, however, a proceeding against the decedent's estate would be considered equivalent to a proceeding against an American rather than against the forcign fiduciary.

Fifteen other tax treaties also contain provisions for mutual assistance in collection, but these are restricted to collections which insure that exemptions and reduced taxes established in the treaties are not enjoyed by those not entitled to them. For a general discussion of tax treaties, see Owens, United States Incomc Tax Treaties: Their Rolc in Relieving Doublc Taxation, 17 RuTGERS L. REv. 428, 451 (1963).

The extradition treaties entered into by the United States do not include tax evasion as an extraditable offense. Yet, many of these treaties do provide for extradition for perjury, and section 7206(1) of the Code, which prohibits false returns, has been held to be a "perjury" statute. Kolaski v. United States, 362 F.2d 847, 848 (5th Cir. 1966). It has also been held that falsification of income tax returns will subject persons to the general federal perjury statute, 18 U.S.C. \& 1621 (1964). United States v. Noveck, 273 U.S. 202 (1927). 
courts. One purpose of this article is to point up the difficulties that can be encountered by OIO in the application of its collection procedures against the foreign fiduciary of a deceased nonresident taxpayer's estate and to examine the dilemma which the fiduciary may face.

The need to reconcile competing goals of OIO will also be considered. Arguably only a rigid and aggressive enforcement policy can deter tax evasion abroad. If there is no question as to liability on the basis of the broad language of the Code and the Regulations, OIO should attempt to collect the full amount of taxes, interest and penalties. On the other hand, OIO must be sensitive to the need to balance its tax collection goals with the need for cooperation and restraint in tax collection in the international area. As the director of OIO has noted:

What we visualize in the international area is the world wide application of methods and systems which have been developed and applied within nations. This will demand even greater cooperation among nations; and between the Service, the international enterprise, and the jet-age citizen. ${ }^{7}$

This is especially true when a foreign fiduciary is involved; for in that situation problems are particularly likely to arise.

\section{The Impact of Death on Tax Collection Against NONRESIDENTS}

Although OIO activities are hampered by inability to sue in foreign courts or to use the extensive tax collection machinery available to agents in the United States, ${ }^{8}$ while a delinquent taxpayer remains alive OIO does have compensating aids at its command. ${ }^{9}$ The taxpayer's assets in the United States can be seized and funds or other property which he sends back to the United States can be intercepted..$^{10}$ The taxpayer may no longer be welcome

7. Fox, Functioning of the Office of International Operations, N.Y.U. 22nd INST. oN FED. TAX. 735, 748 (1964).

8. Balter, How the Office of International Operations Enforces U.S. Taxes in Foreign Countries, 22 J. TAx. 356, 359, 360 (1965).

9. Newman, supra note 5 , at 202-04.

10. The Code provides several alternative methods for the collection of revenue. Sections 6321 and 6332 of the Internal Revenue Code of 1954 provide that at the time an assessment is made a lien arises on "all property and rights to property" belonging to a taxpayer who has refused or neglected to pay any tax. The Service is authorized to collect the tax by levy against all property or rights to property either belonging to the taxpayer or on which there is a lien. INT. REv. CoDE of 1954, \& 6331 (a). The Code also provides for resort to the courts if necessary. Id. $\$ 7403(\mathrm{a})$.

In addition to the general lien for unpaid taxes, special liens arise with respect to the estate and gift tax. Id. \& 6324. The special lien for estate tax attaches at the date of the decedent's death to every part of his gross estate. With a minor exception, all persons receiving property includible in the estate are personally liable for the estate tax to the extent of the value of such property on the date of the decedent's death. The special lien for gift tax attaches upon all gifts made during the calendar year for the amount of gift tax imposed on gifts during that year. If the gift tax is not paid when due, the donee of any gift becomes liable for the tax to the extent of the gift received by him. The special estate or gift tax lien is enforceable for a period of 10 years unless the tax is 
at the United States embassy or legation; his relations with a foreign government friendly to the United States may be strained. Foreign officials who learn that OIO is proceedings against an American residing abroad may commence a tax investigation of their own. In addition, if the taxpayer returns to this country, he may be forced to pay a heavy price in interest and penalties for his delinquency. ${ }^{11} \mathrm{He}$ is well aware that he is risking criminal prosecution for a willful failure to comply with the tax law. ${ }^{12}$ It is therefore probably safe to say that, even when residing abroad, the persons upon whom taxes are imposed remain quite sensitive to the effective tax collection procedures which can be exerted on them from the United States. In effect, the delinquent taxpayer must choose between completely divorcing himself from all contacts with the United States or paying the taxes due. By and large, nonresidents can be counted on voluntarily to comply with our tax laws once their delinquency has been discovered and pressure has been applied by OIO so long as the taxpayer is unwilling to sever all of his contacts with this country.

Even if a delinquent taxpayer does break all contacts with the United States during his life, his death brings a drastic change. The struggle with the taxpayer is terminated, and the OIO must deal with a new party, the decedent's executor or administrator. If the taxpayer has resided abroad for many years and all or a substantial part of his assets are located outside of the United States, the decedent's representative is likely to be a foreign fiduciary. While the fiduciary will be located abroad, it may have contacts with the United States which can serve as a basis for jurisdiction. This is especially true where a corporate fiduciary such as a bank is involved.

Such a fiduciary is situated in a new position and thus possesses a wholly new outlook. The foreign fiduciary is a national of another country and owes no allegiance to the United States. To it, declarations of the United States Congress and the courts of the United States with regard to the imposition and the collection of taxes are not supreme. It will look to its native country for the determination and declaration of its rights and duties. Much of the leverage which OIO agents had against the decedent is inapplicable against

paid in full. An estate tax lien may be divested, however, from that portion of the gross estate used to pay claims against the estate and administration expenses and, in specified cases, from that part of the property which has been transferred to bona fide purchascr, mortgagee, or pledgee for an adequate and full consideration, but a like lien is substituted upon the consideration received. Treas. Reg. \$ 301.6324-1(a) (2) (i), (iii) (1954).

The Service may effectively assert a lien against all property found within the jurisdiction of the United States in order to satisfy amounts owing, and the concept of property "within the jurisdiction of the United States" is a very broad one. Comparc Equitable Life Assurance Society v. United States, 331 F.2d 29 (1st Cir. 1964) (tax lien enforced on taxpayer's endowment policies although taxpayer bad disappcared) with United States v. Bess, 357 U.S. 51 (1958) (lien restricted to cash surrender values of policies at death of insured).

11. Failure to file returns and pay taxes due will obligate the taxpayer for all taxes due, interest at $6 \%$ per annum under section 6601 of the Code, and penalties of up to $25 \%$ of the tax for failure to file a return under section 6651 or $50 \%$ of the tax for fraud under section 6653

12. INT. REv. CODE of $1954 \S \S 7201,7203,7206,7207,7210$. 
the fiduciary as it will not be moved by the same pressures and motives which concerned the decedent. Moreover, while the decedent's motive may simply have been tax evasion, this may not (and probably will not) be the moving force behind the foreign fiduciary's refusal to pay taxes which are said to be due. The fiduciary owes its paramount loyalty to the beneficiaries of the estate, and its primary duty is to preserve the estate for their benefit. The fiduciary may come to find that while under the Internal Revenue Code and Regulations the decedent is said to be subject to tax by the United States, the estate has either no assets or insufficient assets falling under United States tax enforcement powers. Likewise, the fiduciary may be uncertain as to whether it is subject to the jurisdiction of the United States courts. Assertion of jurisdiction by United States courts over the fiduciary or the estate might well be rejected by a foreign court. And even if jurisdiction were found to exist, the beneficiaries might demand that taxes which cannot be enforced not be paid. All of these possibilities contribute to the uncertainty of the fiduciary's position.

\section{Setring the Stage for Testing Tax Coldection}

For the purpose of testing the tax collection powers of OIO, rare (but not unlikely) circumstances are assumed. The hypothetical situation would be as follows: a foreign fiduciary has been appointed as the executor of the will of a nonresident. The estate and the decedent are subject to taxation under the laws of the United States. The estate has little or no assets within the United States which are available to satisfy the taxes owing. For convenience, such an estate will be referred to hereafter as a "foreign asset, foreign fiduciary estate."

OIO's initial problem will be to discover the existence of such an estate..$^{13}$ For example, in the Omar case, ${ }^{14}$ OIO was not aware of the existence of the

13. See Eichel, supra note 5, at 29. In addition to information gathering techniques used domestically, international tax treaties aid OIO in finding delinquent taxpayers residing abroad. Between treaty countries there is a constant exchange of data. See Newman, supra note 5, at 206,207. If, for instance, an American decedent died a resident or domiciliary of Canada, his executor would file papers in connection with the Canadian administration of his estate and, pursuant to the treaty provisions (13 U.S.T. 382, Arts. VII-IX (1962), T.I.A.S. No. 4995), Canadian officials would forward pertinent information to OIO. Even in a nontreaty country, such as Mexico, informal relations between the foreign taxing agency and OIO agents have grown up, and the practice of exchanging information is prevalent. See Balter, supra note 8, at 360 n.18; Newman, supra note 5, at 208.

Presence of a nonresident decedent's property within the United States may bring tax delinquencies to light upon the death of the individual since there are special provisions in the Regulations designed to bring forth this information. Treas. Reg. \& 301.6325-1 (b) (4) - (c) (2) (1954). Under threat of personal liability, any person in the United States in possession of a decedent's property is required to assume the reporting role of an executor where no fiduciary is appointed or acting within the United States. Treas. Reg. $\$ \S 20.2002-1,20.2203-1$ (1958). Consequently OIO often receives unsolicited reports from United States banks and brokerage houses with which a nonresident decedent had an account.

14. United States v. Onuar, S.A., 210 F. Supp. 773 (S.D.N.Y. 1962), rev'd sub 
foreign corporation, against which it ultimately assessed more than nineteen million dollars in delinquent taxes, until the corporation filed a tax return requesting a small tax refund. ${ }^{15}$ Once this existence is known, OIO's basic problem will be to establish quasi in rem jurisdiction over the assets of the estate, or to gain personal jurisdiction over someone who can be held liable for the taxes due.

The Code and Regulations speak in broad terms, constantly referring to "any person," "any books, papers, records" and "all property." If taken literally, the language of the Code and Regulations could be thought of as actually determining OIO's right to impose obligations and sanctions on foreigners without regard to their citizenship, residence, or jurisdictional contacts with the United States. Yet the Service has never fully pressed such an interpretation of the Code and the Regulations. ${ }^{16}$ In practice, it is the rare case in which the Service finds that jurisdictional problems block the use of its collection procedures. It is an even rarer case in which the Service meets any real opposition to its demands. However, due to the potency of its normal collection procedures, OIO agents in the field may not be adequately aware of the jurisdictional limitations on the assertion of tax claims in court.

Special procedures have not been adopted by OIO for handling a foreign asset, foreign fiduciary estate because one does not present itself often. Accordingly, if such a situation comes to light, OIO attempts to enforce its tax claims immediately. Action by OIO can be attempted along one or all of three distinct routes: (1) by proceeding directly against the fiduciary, as the representative of the estate, thereby looking to the assets of the estate for satis-

nom. United States v. First Nat'l City Bank, 321 F.2d 14 (2d Cir. 1963), aff'd en bane, 325 F.2d 1030 (2d Cir. 1964), rev'd, 379 U.S. 378 (1965). For discussion of this case, sce pt. III, section A of this article infra.

15. See United States v. First Nat'1 City Bank, 379 U.S. 378, 385 (1965).

16. The Service has tried to equate the power to impose and assess taxes and jurisdiction to collect them. See United States v. Montreal Trust Company, 358 F.2d 239, 249 (2d Cir.), cert. denied, 384 U.S. 919 (1966):

Before the District Court the government bluntly asserted that "The Commissioner assessed the tax in the State of New York where the tax accrued and there is no reason in the world why that determination should not satisfy jurisdiction here," referring to jurisdiction over a man who never comes to this State of New York physically, who never sets foot in a hotel in New York [but who] may be served in the rice paddy in Indochina. Statement by Government Counsel to District Court, September 10, 1964. The district court, 235 F. Supp. 345, 349, rejected this "presumption of jurisdiction from assessment" argument of the government, stating "Plaintiff's final contention is that even though there is no such evidence ['that Klein, as an individual, in 1944, 1945 and 1946, transacted business in New York'], such a finding can be based upon the mere fact that the Internal Revenue Service assessed income taxes against Klein for those ycars." No pertinent authority is cited for this proposition and in my opinion it is without merit. ... If plaintiff's contention were sound, no hearing on the question of fact would ever be necessary, and all that the government would need to do to sustain the service, at least in the first instance, would be to produce a certified copy of the tax assessment. I am unwilling thus to cxtend the presumption referred to in [Halle v. Commissioner, 175 F.2d 500, 502 (2d Cir. 1949, cert. denied, 338 U.S. 949, 70 S. Ct. 485, 94 L. Ed. 586 (1950)]. 
faction of the taxes due;17 (2) by proceeding against the fiduciary, in its individual capacity on the theory of personal liability, thereby looking to the fiduciary's personal assets to satisfy the tax debt $;^{18}$ or (3) by proceeding against any transferee, ${ }^{10}$ to the extent he has received the assets of the estate.

When the foreign fiduciary of a foreign asset estate hears from OIO, it must decide whether it will cooperate with the United States and satisfy the taxes said to be due. ${ }^{20}$ In making this decision it faces numerous problems.

17. See Treas. Reg. \$ 20.2002-1 (1958).

18. See 31 U.S.C. \& 192 (1964):

Every executor, administrator, or assignee, or other person, who pays, in whole or in part, any debt due the person or estate for whom or for which he acts before he satisfies and pays the debts due to the United States from such person and estate, shall become answerable in his own person and estate to the extent of such payments for the debts so due the United States, or for so much thereof as may remain due and unpaid.

Treas. Reg. $\$ 20.2002-1$ (1958) explains that as used in the statute the word "debt" includes a beneficiary's distributive share of an estate, and the Supreme Court has held that the phrase "debts due to the United States" includes tax obligations not yet reduced to judgment or assessnients so long as the executor has been made aware of the obligation. Price v. United States, 269 U.S. 492 (1926). There is some support in the cases for the proposition that section 192 is applicable only to insolvent estates on the theory that the section was enacted to implement an earlier act granting the United States status as a preferred creditor when a taxpayer is insolvent or an estate is inadequate to satisfy all creditors. For a close analysis of the section which concludes that a distribution which itself creates insolvency is probably sufficient to support liability, see Ferguson, The Fiduciary's Personal Liability for Federal Taxes of the Decedent and His Estate: The Problems of Distribution and Partial Distribution, N.Y.U. 25TH INST. ON FED. TAX. 1185, 1197 (1967).

19. See INT. REv. Cone of 1954, § 6901.

20. Under the Code, where tax liability exists, foreign fiduciaries of nonresident decedents' estates are expected to, and by and large do, comply voluntarily with our tax laws. Assuming liability for United States estate taxes is accepted by a foreign fiduciary, the fiduciary would prepare and file a preliminary notice form and an estate tax return. Id. $\$ \S 6018,6036$. See also Treas. Reg. $\$ \$ 20.6018-2,20.6036-1$ (1958). If the foreign fiduciary disagreed with the propriety of an assessment, it would proceed along the normal routes to contest any proposed deficiency in tax. If necessary, income tax returns and gift tax returns would also be filed on behalf of the decedent. Treas. Reg. $\S 1.1-1$ (b) (1956). INT. REv. CoDE of 1954, \& 6012(b) (1) imposes a duty on the representative of a decedent to make and file income tax returns required for the decedent. Section 6903 (a) of the Code invests the fiduciary with all of the decedent's rights and obligations upon the filing of a Notice of Fiduciary Relationship (Form 506). Treas. Reg. \& $25.6010-1$ (b) (1958) requires a decedent's representative to file a gift tax return for him if a return is due and the decedent dies prior to its being filed. The amount of gift tax due, if any, may be open to question due to problems of valuation and information gathering. The gift tax is imposed upon transfers by citizens irrespective of the situs of the property transferred. INT. REv. CoDE of 1954, \$\$ 2501, 2511. See MacDonald, Ex'rs v. United States, 139 F. Supp. 598 (D. Mass. 1956).

If, however, the foreign fiduciary decides not to file returns and the OIO has become aware of the decedent's death and wishes to pursue actively the collection of the taxes due, the tax liability will be determined and assessed and the OIO will then attempt collection. As a first step in the assessment-collection process, OIO might simply write to the fiduciary evidencing its awareness of the situation, inform the fiduciary of its obligations to file a preliminary notice form, and offer to assist in this regard. If a satisfactory response is not received, the Director of OIO is authorized to investigate the matter himself and to summon any person having relevant information, books, papers, or other data concerning the liability of anyone who has failed to make a return. INT. REv. Cope of 1954, \& 7602. Furthermore, the Director is authorized to make up tax returns for the estate from the Director's own knowledge and from such information as he could obtain from testmiony or otherwise. Fis return is prima facie "good and sufficient for all legal purposes" and has effect whether or not he can gain personal jurisdiction over the foreigu fiduciary. Id. $\S 6020(\mathrm{~b})$. 
The fiduciary cannot be sure that the foreign court in charge of administering the decedent's estate would find that the United States has the power to impose taxes on the decedent and the fiduciary an obligation to pay. If the fiduciary does not attempt to gain a judgment in the foreign court, by paying the tax it runs the risk of having the beneficiaries of the estate subsequently attack its payment. In such an event, the fiduciary may be forced to atteinpt to convince the Service that it is entitled to a refund and may find itself litigating that question in the courts of the United States. ${ }^{21}$ Even if the fiduciary is wise enough to seek a determination of its rights and duties abroad, it is by no means clear that it will be able to obtain one. The foreign court may refuse to determine the right of the United States under foreign law to impose a tax on the decedent. The foreign court may feel that in absence of an actual suit against the fiduciary, a justiciable controversy has not yet arisen. Or, the foreign court could refuse to render an opinion on the ground that by deciding that the United States Congress acted properly in imposing taxes against the decedent, the court would be aiding the United States in enforcing its tax judgments abroad. ${ }^{22}$

Other problems may also exist. Estate tax may have been assessed on the theory that the decedent was a citizen at his death. Even if the fiduciary is able to satisfy itself that the foreign court would hold that citizenship is a proper basis for United States taxation and that a tax levied on that basis should be paid, the fiduciary must somehow assure himself that the decedent actually was an American citizen at his death. ${ }^{23}$ OIO may wrongfully claim

Provisions extending the statutes of limitation aid the Service in collection from nonresident delinquent taxpayers. In general, an amount of income, gift, or estate tax must be assessed against a taxpayer, if at all, within three years after the date of filing of the particular return. Id. $\$ 6501$ (a). In the case of a transferee, the period of limitations will not expire until one year after the expiration of the time within which assessment must be made against the transferor, and, in some instances, the Code provides for further extension of that period. Id. $\S 6901$ (c), (d)-(f). If collection of tax is hindered or delayed because property of a taxpayer is situated or held outside the United States or is removed from the United States, the period of limitations will not run against OIO and the fiduciary and the estate will remain indefinitely liable. Id. $\$ 6503$ (c).

The statute of limitations for commencement of criminal proceedings is either three years or six years, depending on the offense, but the running of the statute is tolled while the person alleged to have committed the offense is outside the United States or is a fugitive from justice. Id. $\$ 6531$. See generally Carrigan, Tax Crimes-Statute of Limitations-Tolling Provisos, 11 TAX L. REv. 137 (1956).

21. A similar possibility arose in the Omar case, discussed in pt. III, section A of this article infra. When it was suggested that after satisfying a judgment in the United States, Citibank might find itself liable abroad and therefore have to seek recoupment in the United States, the Service stated on oral argument that it would oppose such a claim. United States v. First Nat'l City Bank, 379 U.S. 378, 402 (1965).

22. In attempting to enforce a United States tax judgment in Canada, on appeal to the Supreme Court of Canada, the Service attempted to argue that the action was not one to enforce its revenue laws but rather only a stit on the judgment, which created a new cause of action based on the promise to pay a compromised claim. United States v. Harden, 41 D.L.R.2d 721 (Can. 1963). The court would not accept the distinction and suggested that it would always look behind a judgment to the nature of the cause of action in order to avoid enforcing foreign revenue claims, directly or indirectly. Id. at

23. See note 3 supra. 
that a particular asset within the United States belonged to the estate, or there may be a dispute as to whether particular property constitutes estate property. It is not certain that the fiduciary may appear specially in the courts of the United States to obtain a determination on these matters. ${ }^{24}$

The fiduciary may also be uncertain as to the extent of its obligation to cooperate with the United States Government. If the foreign court has not declared that the fiduciary is under a duty to satisfy taxes imposed by the United States, the fiduciary may feel justified in refusing to inform the OIO of any underestimation of the value of the estate, ${ }^{25}$ or transfers made by the decedent which are subject to the gift tax, or assets within the United States over which OIO could assert quasi in rem jurisdiction. It may feel an obligation to the beneficiaries of the estate to withhold this information and attempt to retrieve assets which OIO might reach.

Practically, any attempt by a foreign fiduciary to come to this country, or to employ agents in this country, to remove estate assets from the United States in order to put them outside of OIO's jurisdiction would meet active resistance from the Service. ${ }^{26}$ Tactics which might be employed by the Service are illustrated in United States $v$. Robbins. ${ }^{27}$ There, the Government's tax claims were based upon jeopardy assessments made by the Commissioner. Service could not be made against Robbins and his wife since they were residing in Mexico. ${ }^{28}$ Upon their return, Robbins and his wife were placed under immediate surveillance. The Service then filed an application for a writ of ne exeat republica claiming that Robbins was in the process of liquidating all of his assets in the United States and transferring them to Mexico. The writ, issued ex parte pursuant to section 7402 (a) of the Code, ${ }^{29}$ is in the

24. The division of authority on this point is noted in the Omar case, United States v. First Nat'l City Bank, 379 U.S. 378, 391.

25. See note 20 supra.

26. See note 14 sipra. Once the Service learns that a nonresident decedent owned stocks or bonds in any corporation organized or created in the United States, the Service may require the corporation or its transfer agent to file a return disclosing pertinent information about the securities registered in the decedent's name. Treas. Reg. $\$ 20.6001-$ 1(d) (1958). The Regulations make provision for insuring the payment of taxes due prior to the transfer of such securities by requiring a special transfer certificate for securitics owned by a nonresident where a fiduciary has not qualified within the United States. A domestic corporation or its transfer agent will not transfer stock registered in the name of a nonresident decedent without first obtaining this certificate and receiving evidence that the transfer may be made without liability. Banks and trust companies, and all those in actual or constructive possession of the property of nonresidents, must also obtain transfer certificates before transferring such property. Treas. Reg. $\$ 20.6325-1$ (a) (1958). Cf. Rev. Rul. 55-160, 1955-1 Cukr. BuLl. 464. No certificate is necessary if the total gross estate situated in this country as of the day of death is less than $\$ 2,000$. A statement in good faith from the executor or other person in possession of the facts indicating that the total value of property was under $\$ 2,000$ is sufficient to relieve the transferor of such property from liability. No transfer certificate is required for any bonds owned by an alien nonresident decedent if on the day of death the bonds were not physically in this country.

27. 235 F. Supp. 353 (E.D. Ark. 1964).

28. See notes $47-48$ infra and accompanying text.

29. INT. REV. CODE of $1954, \S 7402$ (a) provides as follows:

JURISDICTION OF DISTRICT COURTS. (a) To Issue Orders, Processes 
nature of an order requiring equitable bail. Under the writ, Robbins would be required to post bail of $\$ 200,000$ or be committed to jail. The court found that the use of the writ would be justified where there was (1) a threatened departure of the defendant from the jurisdiction; and (2) a danger that the court would lose power to give effective relief due to its loss of control over the defendant. ${ }^{30}$ But the court did not find that the taxpayer intended to leave the jurisdiction of the United States or that his departure would substantially prejudice the collection of taxes. It therefore vacated the writ and released Robbins on his personal recognizance. Nonetheless, the case underscores the difficulty a fiduciary would have in attempting to remove estate assets from the United States once OIO became aware of them and knew that taxes were due. The assets are vital to OIO-unless they remain in the United States and are adequate to satisfy the taxes due, OIO may have to face the problems of collecting from a foreign asset estate.

\section{Tax Colifection From a Foreign Asset, Foreign Fiduciary Estate}

In determining its ability to collect taxes from a foreign asset, foreign fiduciary estate, OIO may assume congressional power to impose the taxes due. $^{31}$ Nonetheless, two important questions remain: (1) does Congress have the power to decree that tax collection procedures shall have extraterritorial effect; and if it does, (2) when, if ever, did Congress intend that tax collection procedures apply extraterritorially and that United States courts take jurisdiction over nonresident executors? In two recent cases the Service successfully established such international tax collection powers.

\section{A. The Omar and the Montreal Trust Company Cases}

In late 1962, the Federal District Court for the Southern District of New York decided the Omar case. ${ }^{32}$ The Commissioner of Internal Revenue had assessed over 19 million dollars in taxes, interest and penalties against

and Judgments.-The district courts of the United States at the instance of the United States shall have such jurisdiction to make and issue in civil actions, writs and orders of injunction, and of ne exeat republica, orders appointing receivers, and such other orders and processes, and to render such judgments, and other decrees as may be necessary or appropriate for the enforcement of the internal revenue laws. The remedies hereby provided are in addition to and not exclusive of any and all other remedies of the United States in such courts or otherwise to enforce such laws.

30. 235 F. Supp. 353, 356 (E.D. Ark. 1964).

31. Textwriters on international law and international taxation assert that a sovereign's right to impose tax is virtually unlimited. See Norr, Jutrisdiction to Tax and International Income, 17 TAX L. REv. 431 (1962); Wurzel, Foreign Investnent and Extraterritorial Taxation, 38 CoLUs. L. REv. 809, 815, 817, 826 (1938). See text accompanying note 93 infra.

32. United States v. Omar, S.A., 210 F. Supp. 773 (S.D.N.Y. 1962), rev'd sub nom. United States v. First Nat'l City Bank, 321 F.2d 14 (2d Cir. 1963), aff'd cnl banc, 325 F.2d 1020 (2d Cir. 1964), rev'd, 379 U.S. 378 (1965). 
Omar, S.A., an Uruguayan corporation. Omar did not maintain an office in the United States and simply traded securities through accounts with several New York brokerage houses. It had realized substantial income through the purchase and sale of securities in the United States, on which a tax was allegedly due. When OIO suggested the possibility that Omar was liable for a substantial amount of tax, officers of Omar began to remove its assets from the United States and in large part succeeded in liquidating its securities and transferring funds out of the country. First National City Bank (Citibank), also named as a defendant in the suit, had held assets of Omar in its main office in New York which were transferred to its branch office in Montevideo, Uruguay. Personal jurisdiction was acquired over Citibank but was never obtained over Omar.

In its complaint, the Service sought a finding that Omar was indebted to the government for unpaid taxes; that a valid lien existed in favor of the Service on all property or rights belonging to Omar; that all defendants be enjoined from transferring or disposing of Omar's property; that the District Court order the return of all Omar's property to the jurisdiction of the Court; and that the Court order the foreclosure of the Service's lien and the sale of any of Omar's property held by the defendants. ${ }^{33}$ The Service proceeded under section 7402 of the Code, which grants the district courts of the United States jurisdiction to issue at the request of the United States "decrees as may be necessary or appropriate for the enforcement of the internal revenue laws." 34

Citibank did not oppose the application of the injunction within the United States but argued that it should not be applicable to its foreign branches since the court had no power over property held there. The District Court recognized that it might not have effective power over persons outside its jurisdiction, but it accepted the Service's argument that personal jurisdiction over Citibank in New York gave the court power to compel performance of acts within or without the United States. ${ }^{35}$ It issued a temporary

33. 321 F.2d at 17 (summary of the Service's complaint by the appeal court).

34. See note 29 sitpra.

35. The court cited United States v. Ross, 302 F.2d 831 (2nd Cir. 1962), and First Nat'l City Bank v. IRS, 271 F.2d 616 (2d Cir. 1959), cert. denied, 361 U.S. 948 (1960). $210 \mathrm{~F}$. Supp. at 775. In the First National City Bank case the power of a district court to require the production of records held in branch banks pursuant to a summons served upon its home office was sustained. See notes 110-11 infra.

The motion for preliminary injunction was directed against Lazard Freres \& Co., Lehman Brothers, Belgian-American Banking Corp., Belgian-American Bank \& Trust Co., First National City Bank of New York and First National City Trust Co. The last four of these defendants submitted affidavits that they no longer held any property or rights to property of the defendant. The court found that with the apparent exception of the First National City Trust Co. and Belgian-American Bank \& Trust Co., (1) all of the defendants had some connection with the transfer of defendant's property outside the jurisdiction of the United States and (2) there was no showing that their foreign branches or agents did not still hold any of defendant's assets. $210 \mathrm{~F}$. Supp. at 775 . Under this state of facts the court found "sufficient reason" to enjoin all of the defendants except First National City Trust Co. and Belgian-American Bank \& Trust Co, 
injunction. prohibiting Citibank from transferring any of Omar's assets including the monies which had been on deposit at Citibank and which had been transferred to Citibank's branch in Montevideo, Uruguay. The court indicated that it would modify the decree should it be shown that the order violated foreign law. ${ }^{36}$

The appeal to the Second Circuit ${ }^{37}$ was decided in June of 1963. Citibank argued that under New York law, a deposit in its branch bank would not be collectible by Omar in New York, Omar's sole right being against the branch bank in which deposits were made. That being the case, Citibank argued that there was no debt due in the United States, and thus there was no property to which a federal lien could attach. Implicit in the Citibank argument was the assertion that the tax lien statute ${ }^{38}$ did not have extraterritorial effect. At the time, the Service saw no way in which it could gain personal juriscliction over Omar since it was outside of the country. It asserted (1) that its lien could attach in New York, (2) that its lien attached even if the situs of the debt was outside of the United States, and that (3) in any event, the district court's having personal jurisdiction over the officers of Citibank located in New York gave it the power to issue its injunction. ${ }^{30}$

On the Service's first assertion, Judge Moore, writing for the majority, recognized that where personal jurisdiction over a delinquent taxpayer is unobtainable, the Service can proceed in a quasi in rem action to enforce its $\operatorname{tax}$ lien on specific property belonging to the taxpayer so long as that property is within the jurisdiction of the court. Absent personal jurisdiction over Omar, the action could only proceed if Citibank's debt to Omar were within the jurisdiction of the district court. After reviewing the New York cases, Judge Moore determined that accounts in foreign branch banks are not subject to attachment or execution by the process of a New York court served in New York on the main office of the bank.40

The Service's third assertion had been accepted by the District Court on the basis of cases sustaining its power to require the production of records in branch banks pursuant to a summons served upon the home office. ${ }^{41}$ Judge

36. $210 \mathrm{~F}$. Supp. at 775.

37. United States v. First Nat'l City Bank, 321 F.2d 14 (2d Cir. 1965), noted in 64 Colum. L. Rev. 774 (1964), 62 Mrch. L. Rev. 1084 (1964), 42 Texas L. Rev. 731 (1964) and 9 VIllaNova L. Rev. 339 (1964).

38. INr. REv. CODE of 1954, § 6321 .

39. 321 F.2d at 17.

40. Id. at 24 .

41. See text accompanying note 35 sipra. That a party whose person and property are completely outside the jurisdiction of the court is free from its direct power is clearly accepted. A more open question would be the propriety of coercing such a party indirectly by using the court's equity powers against his property located outside of the jurisdiction of the court. Dissenting in the Omar case, Mr. Justice Harlan said:

We should first consider the question in its starkest form. Assuming that there is no quasi in rem jurisdiction over the property .... and no reasonable likelihood of obtaining personal jurisdiction over Omar, why should the court not use its naked power, to the extent that it could be brought to bear on others 
Moore cited the absence of personal jurisdiction over the taxpayer in this case as a crucial factor in distinguishing the cases relied on by the District Court. He said: "Absent jurisdiction over the person of Onar, this action can proceed only on the ground that Citibank's debt to Onar is within the jurisdiction of the district court." 42

Judge Moore therefore had to consider the Service's second assertionthat the tax lien statute had global effect. Only if the lien were valid could Citibank be personally liable for wrongfully refusing to surrender the property. In finding that the tax lien statute does not have global effect, Judge Moore stated:

If taken literally, the statute might be susceptible to this interpretation, but to so construe it would do violence to the settled principle of statutory construction that legislation is meant to apply only within the territorial jurisdiction of the United States unless a contrary intention appears.... The Supreme Court has made manifest its reluctance to read an extraterritorial force into statutes when to do so would extend coverage beyond places over which the United States has legislative control ... or would interfere with the rights of other nations....

-...

Absent an explicit indication to the contrary, there should not be attributed to Congress an intent to give the courts of this nation, in this highly sensitive area of intergovernmental relations, the power to affect rights to property wherever located in the world. The apparent necessity of tax treaties underscores the conclusion that Congress has seen fit to handle this problem in another manner. ${ }^{43}$

Judge Hays dissented and pointed out that the order of the district court did not purport to establish or enforce any lien; it was a simple order to Citibank in New York, over which the court had personal jurisdiction, to keep the property of the taxpayer which it held. Judge Hays did not clarify how the Service would be able to recover the monies on deposit in Citibank's foreign branch if the injunction were upheld. He inquired:

situated as was Citibank, to tie up Omar's property all over the world for the avowed purpose of coercing Omar into paying its taxes?

Use of judicial equity powers to coerce a party over whom the court has no jurisdiction or likelihood of obtaining jurisdiction is unheard of. The statute [IRC \& 7402(a)] authorizing courts to render such decrees as may be "necessary or appropriate for the enforcement of the internal revenue laws" clearly intends that courts use only their traditional equity powers to that end. It should not be interpreted as an authorization to employ radically new and extremely far-reaching forms of coercive action in a more free-wheeling approach to international than to domestic cases. Neither the Government nor the Court argues for such an extraordinary judicial use of power. Suffice it to say that if the contrary position were taken, serious constitutional problems would arise.

United States v. First Nat'l City Bank, 379 U.S. 378, 389 (1965) (footnotes omitted). 42. 321 F.2d at 19, citing Hanson v. Denckla, 357 U.S. 235 (1950). In Hanson, the Supreme Court found that the State of Florida could not exercise jurisdiction over a fiduciary located in Delaware since, although the settlor was domiciled in Florida, the fiduciary had insufficient contracts with the state to support jurisdiction.

43. 321 F.2d at 23,24 . 
Even if it should be granted that in the present proceeding the government could not recover property of the taxpayer held by a foreign branch, is this court now prepared to hold, for example, that there is no possibility that a receiver appointed under the authority of $\S 7402$ (a) would be able to proceed against taxpayer's property under any circumstances or anywhere other than New York?

The dissent did not consider the impact of the amendments to Rule 4 of the Federal Rules of Civil Procedure which were ordered by the Supreme Court ${ }^{45}$ in January of 1963 , to become effective on July 1 , although these amendments would prove to be vital in upholding its view of the Omar case in the Supreme Court. ${ }^{46}$

As originally drawn, Rule 4 (e) created doubt as to whether, in absence of a federal statute, service could be made upon a nonresident under state statutes and rules, such as nonresident motor vehicle laws and other state long-arm statutes, which predicate in personam jurisdiction over a nonresident upon the doing of an act in or maintaining some other valid contact with the state. ${ }^{47}$ As amended in 1963, Rule 4(e) now provides in its relevant parts:

\begin{abstract}
Whenever a statute of the United States or an order of court thereunder provides for service of a summons $; * ;$ upon a party not an inhabitant of or found within the state in which the district court is held, service may be made under the circumstances and in the manner prescribed by the statute or order, or, if there is no provision therein prescribing the manner of service in a manner stated in this rule. Whenever a statute or rule of coutrt of the state in which the district court is held provides $* * *$ for service of a summons ** * upon a party not an inhabitant of or found within the state, *** service may *** be made under the circumstances and in the manner prescribed in the statute or rule. ${ }^{48}$
\end{abstract}

The italicized second sentence of the statute was added in 1963. The change in the rules appears to have been made in order to permit the federal courts to make use of state long-arm statutes and thereby maintain federal court service of process on a par with the courts of the state.

In October of 1963, the Omar case was reargued before the Court of Appeals sitting en banc, ${ }^{49}$ and Judge Moore's decision was affirmed. The

44. 321 F.2d at 26.

45. See 374 U.S. 865 (1963). 28 U.S.C. \& 2072 (1964) gives the Supreme Court the power to prescribe rules of practice and procedure for federal district courts and provides: "All laws in conflict with such rules shall be of no further force or effect after such rules have taken effect."

46. See text accompanying note 64 infra.

47. 2 J. Moore, Federal Practice T 4.32 (1967); Kaplan, Amendments of The Federal Rules of Civil Procedure, 1961-1963 77 HARv. L. REv. 601, 619-22 (1964). part:

48. Rule 4(f) was also amended to conform to Rule 4(e). It now provides in relevant

All process other than a subpoena may be served anywhere within the territorial limits of the state in which the district court is held, and when authorized by a statute of the United States or by these rules beyond the territorial limits of that state.

49. United States v. First Nat'l City Bank, 325 F.2d 1020 (2d Cir. 1963), noted in 16 Sta.. L. REv. 1101 (1964). 
Service at that time put forth an entirely new contention. Previously, the Service had admitted its inability to gain personal jurisdiction over delinquent taxpayers residing abroad. It now argued:

It is only in the event that the Court concludes that the lien does not attach to such deposits that personal jurisdiction over Omar becomes relevant. In such event the Government should be afforded an opportunity to obtain personal jurisdiction over Omar and the injunction should stand pending such efforts. ${ }^{50}$

The Service seemed to see a possibility of gaining personal service over Omar by making use of section 302 of the New York Civil Practice Law and Rules, a long-arm statute, which had become effective September 1, 1963.51 Any doubt of this was dispelled by the Montreal Trust Company case, ${ }^{52}$ decided by the Southern District of New York in May of 1964.

In Montreal Trust the Service sought the payment of income taxes said to be due from a nonresident alien decedent, the Montreal Trust Company being an executor of the estate. ${ }^{53}$ The Service alleged that Isidore Klein, a Canadian resident and domiciliary, had used his corporate position as managing director of a Canadian distillery to force distributing agents in the United States to pay commissions to his American friends and relatives. The Service argued that under the attribution rules the commissions paid represented taxable income to Klein.

Since the foreign executor bank did no business in New York, originally the Service attempted to serve a summons on the New York correspondent of the executor. This failed when the district court granted the executor's motion to set that service aside. The Service then had the United States ViceConsul personally serve a summons on the bank in Canada pursuant to the New York long-arm statute ${ }^{54}$ which provides, in its relevant part:

A court may exercise personal jurisdiction over any non-domiciliary, or his executor or administrator, as to a cause of action arising from any of the acts enumerated in this section, in the same manner as if he were a domiciliary of the state, if, in person or through an agent he:

1. transacts any business within the state....

There were no estate assets in New York and neither the executor nor the decedent ever personally transacted business in New York. Yet the Service successfully asserted an agency relationship between the decedent and the local distributors whose acts of negotiating and signing a contract on behalf of the decedent and distributing income in New York at the decedent's

50. 379 U.S. at 393.

51. N.Y. CPLR \& 302 (McKinney 1963), as amended, (McKinney Supp. 1967).

52. 35 F.R.D. 216 (S.D.N.Y. 1964).

53. A co-executrix was also served but did not appear in the action.

54. N.Y. CPLR \& 302 (McKinney 1963), as amended, (McKinney Supp. 1967). 
request were found sufficient to sustain jurisdiction under the New York statute.

Counsel for the executor had argued that personal jurisdiction over the foreign estate could not be acquired by service under the long-arm statute for two reasons. First, the New York statute was not applicable to an action brought in a federal court. Second, it would be unconstitutional to apply the statute so as to validate service beyond the boundaries of the United States..$^{65}$

The district court found that the amendments to Rule 4 "plainly mean that a party not an inhabitant or found within the state may be served with summons in a federal court action under the circumstances and in the manner prescribed by state statute." ${ }^{\text {66 }}$ It then concluded that since the New York statute did not specifically prohibit service of process on an executor located outside of the country, the Service could effect service under the authority of the statute. ${ }^{57}$ The court's approval of this application of the state long-arm statute was not modified when the case was reviewed again in October of 1964. ${ }^{58}$ Before an appeal from the decision could be taken to the Second Circuit, certiorari had been granted by the Supreme Court on the Omar case, which was decided early in 1965.

Mr. Justice Douglas delivered the Supreme Court's opinion in Omar. On a rationale similar to Judge Hays' in the court below, ${ }^{60}$ the Court upheld the validity of the injunction against Citibank, reversing Judge Moore's decision in the court of appeals ${ }^{61}$ and upholding the decision of the district court. ${ }^{62}$

Justice Douglas considered the narrow issue of whether the creditor (the United States) could by injunction pendente lite protect whatever rights the debtor (Omar) had against Citibank, which was before the court on personal service. In so defining the issue Justice Douglas explained that if it were clear that the debtor could not be brought within the reach of the district court by personal service, "we would have quite a different case-one on which we intimate no opinion." ${ }^{\circ 3}$ But the New York long-arm statute and the 1963 amendments to Rule 4 of the Federal Rules of Civil Procedure made such service possible. Justice Douglas noted that the amended rules "allow a party not an inhabitant of the State or found therein to be served with a summons in a federal court in the manner and under the circumstances prescribed

55. 35 F.R.D. at 218.

56. Id.

57. Id. at 219.

58. 235 F. Supp. 345 (S.D.N.Y. 1964).

59. United States v. First Nat'1 City Bank, 379 U.S. 378 (1965), noted in 51 A.B.A.J. 376 (1965), 2 TeXas InT'L L. ForuM 119 (1965) and 13 U.C.L.A.L. REv. 13 (1965).

60. See text accompanying note 44 supra.

61. See notes 37 to 43 supra and accompanying text.

62. See notes 32 to 36 sipra and accompanying text.

63. 379 U.S. at 381 . 
by a state statute," ${ }^{\prime 64}$ and cited the lower court opinion in Montreal Trust ${ }^{65}$ with approval. He reasoned that if personal jurisdiction over Omar is ever acquired, the United States will be able to collect from Citibank what the bank owed Omar. Therefore, "[ $t]$ he opportunity to make that collection should not be lost in limine." 66 There was no indication that foreign law would be violated by freezing the Montevideo accounts pending service on Omar. If there were, the district court had retained jurisdiction to modify the order and the district court was open to the Executive Branch should the litigation embarrass United States' diplomacy. ${ }^{67}$

Mr. Justice Harlan, who was joined by Mr. Justice Goldberg in dissent, argued that although the district court had the naked power to issue the injunction, ${ }^{68}$ its order was not " appropriate for the enforcement of the internal reyenue laws" "and, therefore, the court lacked jurisdiction within the meaning of section 7402(a).$^{69}$ In the dissenters' view, the fact that Citibank's officers had sufficient control over the Montevideo branch bank to require compliance with the injunction and could be held in contempt if they failed to was not sufficient reason to uphold the injunction order. Rather they maintained that the Service was obligated to show that at the time the injunction issued in October of 1962, the fund which was to be frozen might be subject to ultimate execution. ${ }^{70}$ Because New York's long-arm statute did not become effective until September $1,1963,{ }^{71}$ ten months after the injunction, and because there was no other substantial theory ${ }^{72}$ under which the Service could have hoped to gain personal jurisdiction over Omar, the injunction should have been dismissed. Even considering the injunction "as of now," the position of the dissenters was that the Service must show, as a matter of both state and federal law, that it was equitable to continue the injunction; and this they found had not been done. ${ }^{73}$

64. Id.

65. 35 F.R.D. 216(S.D.N.Y. 1964).

66. 379 U.S. at 383 .

67. Id. at $384-85$.

68. Id. at 387.

69. Id. at 410 .

70. Id. at 390 .

71. Citibank argued that at the time the injunction was issued it could not be served under the provisions of section 302 since the complaint was filed, and the injunction was issued before the New York statute became effective. The Court's response was that the New York Court of Appeals had indicated that where, as in the Omar case, a suit based on a prior transaction was pending on the effective date of the statute, the statute would apply to all further proceedings, except where it would "work injustice." Id. at 382.

72. The dissenters considered the Service's argument that Omar might voluntarily make a general appearance to defend the suit a "lame suggestion." Id. at 390 n.8.

73. Id. at 391-96. During the course of the argument, counsel for Citibank contended that its foreign banking business would be hurt because foreign depositors would be discouraged from using United States banks for fear that their funds could be reached by American courts. The Court saw no sure way to gauge the seriousness of this probability. In the course of preparing this article inquiry was made of counsel for several leading New York banks in order to determine the effect that the Citibank decision had on their foreigu branch business. In each case, replies indicated that business had not suffered, the general impression being that customers were either unaware of the import 
The dissenters considered that the Service's achievement in the case was to place the Government in a position to "snare only those taxpayers smart and unscrupulous enough to withdraw their funds from the United States, but stupid and uninformed enough, even after this decision, to put the transferred funds in a bank having a United States office."74 Their feelings as to the impact of the case were summarized when they stated that "[i]n order to provide the Government with this toy pistol the Court flexes its muscles in a manner never before imagined."75

When the Montreal Trust case was argued before the Second Circuit in November of $1965,{ }^{76}$ the Service's use of the New York long-arm statute to gain jurisdiction over the foreign executor was unquestioned. It was noted that the Supreme Court had in Omar cited with approval the lower court decision in Montreal Trust on this point. ${ }^{77}$ The petition for certiorari to the

of the decision or unconcerned because of their willingness to satisfy their tax liabilities. Although fear of loss of business has subsided, counsel for one New York City bank with foreign branches did indicate a general dissatisfaction with the Omar decision in banking circles. He was confident that had banking business been clearly affected, Congress would have considered legislation to overturn the decision since its interest in encouraging foreign investment in overseas branches of American banks far outweighs the possibilities of trapping an isolated tax dodger.

On an actual rather than a predicted result of allowing the injunction to stand, Justice Harlan observed that:

As far as Omar is concerned, its property has been taken from its control by a court having jurisdiction neither over the corporation nor over the property... prior to any judgment of liability being entered against it, and during a time when the Uruguayan peso has fallen over $60 \%$.

Id. at 392 .

74. 379 U.S. at 401 . The dissenters were no more satisfied with the Service's landling of the case than they were with the decision reached by the majority of the Court. In reviewing the Service's tactics, Mr. Justice Harlan observed:

The Government's delay in obtaining personal jurisdiction is particularly significant because of the unknowns and imponderables with which the case in its present posture is saturated. Thus, we have no firm indication of what Uruguayan law is with respect to any aspect of this action, no indication of the effect freeze orders would have on this country's banking interests, and Omar, the foreign taxpayer whose interests are most at stake, is not before the Court. Can it be doubted that a decision upon the propriety of the novel use of judicial power here involved could be much better made if the issue were presented in a context with some of the unknowns removed? Had the Government not delayed but, instead, proceeded (if possible) to acquire personal jurisdiction over Omar, and then judgment and execution (if possible), against the Montevideo account, the case could come before us with most of this opaqueness removed. Id. at 394 n.13.

The Service attempted to excuse its failure to attempt to gain personal jurisdiction over Omar by claiming that during the pendency of the action it had altered the theory under which it chose to argue its case, 379 U.S. at 392, 393. This, of course, was due to the decision in the Montreal Trust Company case. See text accompanying note 52 supra. 75. 379 U.S. at 401 . In order to make a decision in its favor more palatable, the Service, by its own action, sharply limited the application of the holding in the Omar case. During the pendency of the action, it amended its regulation (Treas. Reg. \& 301.6332-1 (1954), as amended, T.D. 6746, 1964-2 Curr. BuL. 497) declaring that it would limit its use of temporary injunction orders freezing funds in foreign branches of United States banks so as to reach only funds which were transferred out of this country in order to hinder or delay the collection of taxes. 379 U.S. at 400 .

76. 358 F.2d 239 (2d Cir. 1966), noted in 42 NOTRE DAMSE LAwYer 273 (1966), 15 U. Kan. L. REv. 574 (1967) and 20 VAND. L. REv. 213 (1966).

77. 358 F.2d at 245 . The court also cited Gkiafis v. Steamship Yiosonas, 342 F.2d 546, 549 (4th Cir. 1965), which noted the district court decision in the Montrcal Trtsst Company case with approval. The idea that Rule 4(e) specifically permits extraterri- 
Supreme Court to review the affirmance of the district court's opinion in favor of the Service was denied. ${ }^{78}$ Subsequently, both the Montreal Trust case and the Omar case were settled without further proceedings.

\section{B. The Omar and Montreal Trust Company Cases in Perspective}

The Supreme Court has not of course placed its full stamp of approval on the unbridled use of state long-arm statutes for tax litigation in the federal courts. In fact, it is possible to agree with the conclusions reached by the district court in Montreal Trust concerning the general effect of amended Rule 4 without reaching its specific conclusion that the Service may serve foreign executors under the authority of the long-arm statute in an action for unpaid federal taxes so long as the decedent "transacted business in the state." To bolster its finding upholding service on the foreign executor, the district court in Montreal Trust cited the Advisory Committee ${ }^{79}$ Notes to Rule 4 of the Federal Rules of Civil Procedure, which indicated that the amended rules were intended to have the effect of allowing the federal courts to make use of the new state "long-arm" statutes.

It is quite possible, however, that the draftsmen of the amended rules never intended to allow the use of a state long-arm statute in cases involving federal questions for which the federal courts have exclusive jurisdiction. ${ }^{81}$ It would be plausible to read the amended rules as merely putting the federal courts on a par with state courts in allowing the use of state long-arm statutes in those actions-and only in those actions-which could be brought in the courts of the state.

But perhaps the most likely reading of the rules would find a grant of authority to use extraterritorial service in all cases in which such service is available in state courts, and also in cases involving exclusive federal jurisdiction, if Congress has affirmatively indicated that it desires extraterritorial service of process. Under the first sentence of Rule $4(\mathrm{e}),{ }^{82}$ before extraterritorial service can be made on the basis of a federal statute, there must be some indication of an intention on the part of Congress to provide for service of a

torial service under state law even on federal claims was advanced with citation to the district court decision in the Montreal Trust Company case and the Supreme Court decision in the Omar case. In Hoffman Motors Corp. v. Alfa Romeo S.p.A., 244 F. Supp. 70 (S.D.N.Y. 1965), the district court allowed service of process under procedures established by the New York long-arm statute in order to enable plaintiff to enforce a claim against a foreign corporation which arose under the anti-trust laws. The federal statute involved (15 U.S.C. $\$ 22$ (1964)) specifically provided that suit could be brought against the corporation " in any district wherein it . . transacts business." $244 \mathrm{~F}$. Supp. at 75 .

78. 384 U.S. 919 (1966).

79. The rules which the Supreme Court promulgates are prepared by Committees of the Judicial Conference designated by the Chief Justice of the Supreme Court. Order to Amend the Federal Rules of Civil Procedure, 374 U.S. 865 (1963).

80. See the Advisory Committee Notes to the Rule in 3A W. BArron \& A. Holtzoff, Federal Practice and Procedure 210-11 (C. Wright ed. Supp. 1967).

81. But see note 77 supra.

82. See text accompanying note 48 supra. 
summons upon a nonresident. ${ }^{83}$ Similarly, where the federal court's jurisdiction is exclusive, the second sentence of Rule $4(e)^{84}$ could be interpreted as limiting service under a state long-arm statute to situations where a Congress has affirmatively indicated an intention to provide for service of a summons upon a nonresident.

At the very least, it seems unreasonable to suggest that a state long-arm statute may be used when a federal court has exclusive jurisdiction and Congress has in some way evidenced its intention that extraterritorial service of process not be allowed. If the intention of Congress were thought irrelevant, and a state long-arm statute applied in any federal question suit, Congress would have to act affirmatively if it wished to prevent federal courts from affecting extraterritorial service upon defendants in any case where for counter-balancing reasons, such as its concern for the international situation, Congress did not wish to allow such service to be made. Our traditional adherence to the "territorial principal" of jurisdiction and our courts' respect for the will of Congress on jurisdictional matters ${ }^{85}$ would place such a wide reading of amended Rule 4 in grave doubt.

If the amended rules are read so as to permit extraterritorial service of process, such a finding would not fail for want of congressional power to provide for extraterritorial service of process in tax collection matters. This being a purely federal matter, the question would be whether extraterritorial service would contravene the due process provisions of the fifth amendment. Admittedly, the problem goes beyond the settled issue of the constitutionality of the state long-arm statutes. ${ }^{86}$ But Congress' power to subject citizens to

83. Cf. SEC v. VTR, Inc., 39 F.R.D. 19, 21 (1966) (service of process abroad by Securities and Exchange Commission on foreign bank under provisions of the Federal Rules of Civil Procedure upheld after provisions of the Securities Act of 1933 were interpreted as authorizing service of process abroad).

84. See text accompanying note 48 supra.

85. See Fed. R. Crv. P. 82.

86. Or the appeal of the Montreal Trust Company case to the Second Circuit, Judge Kaufman observed:

Since Pennoyer v. Neff, 95 U.S. 714, 24 L. Ed. 565 (1887), the area in which states are constitutionally permitted to assert their jurisdiction has undergone great expansion. International Shoe Co. v. State of Washington, [326 U.S. 310 (1945)], and McGee v. International Life Ins. Co., 355 U.S. 220 (1957), are among the landmarks pointing the way in this direction. And New York, like many other states, enacting its "Iong-arm" statute with the intention of taking advantage of the "new enclave" opened by these cases. New York Advisory Comm. Rep. (N.Y. Legis. Doc., 1958, No. 13), 39-40: 1 Weinstein-Korn-Miller, New York Civil Practice \& 302.06.

There is no serious challenge on this appeal to the constitutional power of New York to enact $\S 302$. International Shoe Co. v. State of Washington, supra, authorizes a state to assert its jurisdiction over non-domiciliaries with whom it has sufficient minimum contacts, "such that the maintenance of suit does not offend 'traditional notions of fair play and substantial justice'." 326 U.S. at 316, To meet this requirement, New York in enacting $\$ 302$ has not sought to obtain full in personam jurisdiction over non-doniciliaries who transact business within its boundaries. Rather, New York has limited itself to jurisdiction only in those "causes of action" arising out of activity conducted within the state. Since such a limitation of jurisdiction complies with the mandate of International Shoe Co., supra, we are not here presented with a constitutional issue but with a narrow 
extraterritorial service of process has already been clearly decided, ${ }^{37}$ and under the long-arm statute, service upon a nonresident alien is acceptable if grounded on the "transaction of business" within the state. ${ }^{88}$ To date, the courts have not found that Congress has misused its right to levy tax or to provide for the collection of tax internationally. Indeed, in exercising its international taxing authority, Congress has been considered much too timid. ${ }^{39}$ It has been held that jurisdiction may be obtained over the fiduciary on the basis of the acts of the decedent..$^{90}$ The fiduciary is called upon only in his capacity as an executor or administrator to answer for the acts of the decedent rather than for any act of his own, and if a foreign court does not relieve him of the obligation to answer service of process, ${ }^{91}$ due process would seem to be satisfied if provision were made for adequate notice and an opportunity to be heard.

Although the constitutional adequacy of long-arm jurisdiction tends to be measured by the same criteria for both state and federal courts, ${ }^{92}$ a good case can be made for the proposition that the federal courts should have greater power than state courts to assert in personam jurisdiction over nonresident taxpayers. There is a fundamental difference between the federal government's power to tax and the power to tax enjoyed by the states. The federal government has a national power to tax all persons including nonresidents and should be able to strike harder and reach further in its tax collection than the states whose taxes are purely local in nature. ${ }^{93}$ Furthermore, a tax owed by a resident of a sister state can be collected by suit in the sister state. In such a case a question of inconvenience is usually all that is at issue. Federal tax judgments are not normally collectible abroad. When the Service's ability to subject the nonresident taxpayer to suit in the United States is determined, the collectibility of the tax may be at stake.

If Congress has the requisite power, the issue becomes whether Congress intended to permit service of process under state long-arm statutes on foreign

question of statutory interpretation-did Klein, within the meaning of the "longarm" statute, transact business in New York.

358 F2d. at 242.

87. See, e.g., Blackmer v. United States, 284 U.S. 421 (1931); SEC v. Briggs, 234 F. Supp. 618 (N.D. Ohio 1964).

88. See notes $77 \& 86$, and text accompanying note 54, stpra. But see note 107 infra.

89. Wurzel, sitpra note 31 , at 819 ; see Norr, sitpra note 31 .

90. In Rosenfeld v. Hotel Corp. of America, 20 N.Y.2d 25, 228 N.E.2d 374, 281 N.Y.S.2d 308 (1967), the Court of Appeals of New York upheld the constitutionality of obtaining in personan jurisdiction over substituted nonresident executors, by out-of-state service upon such executors, although such nonresident executors had committed no acts and transacted no business in New York.

91. Presumably, the United States would respect a decision of the foreign court which restrained the fiduciary from making an appearance in the courts of the United States. See text accompanying note 36 supra.

92. See United States v. Montreal Trust Co., 358 F.2d 239, 257 (2d Cir. 1966); SEC v. Briggs, 234 F. Supp. 618, 620 (N.D. Ohio 1964) (Timbers, J., concurring in part and dissenting in part).

93. Wurzel, supra note 31 , at $823-24$. 
fiduciaries in tax cases. The Second Circuit in Omar noted the basic canon of construction that federal legislation is interpreted to apply only within the territorial limits of the United States in absence of a clear legislative intent to the contrary. ${ }^{94}$

It can be noted that while no federal statute specifically provides for extraterritorial service of process, the Code and Regulations are written in sweeping terms, generally applying to all persons and all things. Arguably, if nonresidents are subject to tax, there must be effective procedural machinery available to compel them to pay. ${ }^{95}$

Yet there are indications that such a generalization is inaccurate. For instance, the general language of section 7602, which provides the Service with subpoena powers appears at first glance to encompass all persons everywhere, and where the person is a citizen, Congress clearly has the power to provide for such extraterritorial subpoena service. ${ }^{96}$ However, Congress has not made clear that it intends to provide for enforcement of a subpoena outside the United States. Sections 7402(b) and 7604, the enforcement sections in the Code applicable to section 7602 subpoenas, provide for enforcement against "any person"-but only in the judicial district in which such person resides or in the judicial district in which such person is found. Arguably, such lack of enforcement provisions is indicative of a congressional intent to limit the issuance of subpoenas under the Code to cases in which service can be made within the territorial limits of the United States. Moreover, although under certain circumstances there is statutory authorization for the service of a subpoena abroad on a United States citizen in connection with civil or criminal proceedings pending in a United States court, ${ }^{97}$ the statute authorizing extraterritorial service of process does not purport to authorize extraterritorial service of subpoenas issued by administrative agencies of the United States Government.

Even if it is accepted that a fiduciary may be brought within the jurisdiction of the federal courts on the basis of the transactions of the decedent, the value to the Service of such expanded jurisdiction may be questioned. If the Service gains jurisdiction over a foreign fiduciary and demands that the fiduciary return the decedent's property located abroad to the United States, presumably the foreign court will prohibit the removal of the property from the foreign country because to allow this would be to enforce indirectly the tax laws of the United States. ${ }^{98}$

The Service might attempt to take action against the foreign fiduciary

94. See text accompanying note 43 supra.

95. Under this theory, tax treaties are entered into merely to assist in tax collection abroad rather than as the only way in which to make such collection possible.

96. See note 87 supra.

97. 28 U.S.C. $\$ 1783$ (1964).

98. See text accompanying note 4 supra. 
on the theory that it is personally liable for the taxes due.99 In such an event, the fiduciary may argue that the long-arm statute is tied to the act of the decedent so that it only envisions a suit against the fiduciary in its representative capacity as executor. Furthermore, if the fiduciary has not transacted business in the United States, the minimum contacts which due process require in order to subject him to suit here on a personal basis would not exist. ${ }^{100}$ Even if the fiduciary comes to the United States to defend a suit for taxes against the estate, he arguably would be present only in a fiduciary capacity and would not be subject to suit on the basis of his personal liability.

The courts have attached significance to the distinction between action in a personal and in a corporate capacity. In Application of Daniels, ${ }^{101}$ a United States citizen, the president and sole stockholder of a nonresident Panamanian corporation, was located by the Service in the United States and summoned to appear before a special agent to give testimony concerning his personal tax liability. In connection with the investigation, Daniels was asked to bring records of the corporation to the hearing. Daniels argued that if he were compelled to produce the books of the foreign corporation which itself was not subject to service, the Service would be able to gain by indirect means that which it could not obtain by direct action. ${ }^{102} \mathrm{He}$ also argued that to permit the Service to examine the corporation's books and records would infringe principles of international law and comity and violate his rights under the fourth and fifth amendments since he was holding the records in a purely personal capacity and not as corporate custodian. ${ }^{103}$

The District Court for the Southern District of New York agreed. Judge Kaufman recognized the general right of the Service to compel production of corporate and organizational documents by an official custodian who claims the privilege of self-incrimination. Nonetheless, he drew attention to the petitioner's claim that he held the corporate books in his "personal capacity" and that his fifth amendment privilege against self-incrimination allowed him to withhold the books from examination. ${ }^{104}$

99. See note 18 supra.

100. But see text accompanying note 131 infra.

101. 140 F. Supp. 322 (S.D.N.Y. 1956).

102. Id. at 324 .

103. Id.

104. Id. at 327-28. United States v. Ross, 302 F.2d 831 (2d Cir. 1962), a later Second Circuit case which had been heavily relied on by the district court in deciding the Omar case, may foreshadow a narrow interpretation of the Daniels case. In Ross the Service brought an action to subject property of the defendant to the payment of jeopardy assessnents for unpaid income taxes. The corporations involved were foreign based and could not be served with the process. Ross, although a resident of Nassau, Bahamas, was a citizen of the United States. The Service concluded that Ross had failed to report income for prior years and obtained jeopardy assessments upon learning that Ross was transferring assets out of the country. It also obtained an order from the district court which (1) appointed a receiver over Ross's property, (2) directed Ross to deliver his stock (which was located in the Bahamas) in two foreign corporations to the receiver, (3) restrained Ross from transferring any of his own property and (4) restrained Ross from transferring property of the foreign corporations. Id. at 833. 
Similarly, an individual foreign fiduciary or an employee of a foreign corporate fiduciary may come to this country or do his business here, either in his personal or fiduciary capacity or both. In absence of an advance statement by a fiduciary, it remains totally unclear as to what facts would be necessary to prove that an individual found within the United States, or found doing business here, was present in a "personal" capacity rather than a "fiduciary" capacity. ${ }^{105}$ Thus it will be difficult for the fiduciary to prove that he is acting in a "personal" rather than "representative" capacity, and this may sharply limit his ability to rely on the Daniels approach. If, for instance, an employee of a corporate fiduciary were found in the United States while in possession of the estate books and records, what persuasive evidence would he submit to prove that he held the documents in a "personal" capacity? The presumption would in all likelihood be to the contrary.

Even if an individual foreign fiduciary can prove that he is present in the United States only in an individual capacity, his presence makes him subject to suit. Similarly, a foreign corporate fiduciary "transacting business" only for its personal account in the United States would be subject to the jurisdiction of our courts in a personal capacity under a New York State type long-arm statute ${ }^{106}$ if the cause of action for the taxes due could be said to arise from the fiduciary's transaction of business in the state. How closely the fiduciary's activities in this country would have to be related to the administration of a foreign asset estate in order for a court to reach this result is unclear. ${ }^{107}$

The obvious argument for existence of a personal fiduciary liability is that the Code specifically imposes personal liability on the fiduciary without regard to the problems of jurisdiction or collection. ${ }^{108}$ On the other hand, it would seem reasonable for a court to refuse to apply the statute providing for personal liability where a fiduciary could prove both that the Service cannot reach the assets of the estate, and that under foreign law the fiduciary would be denied reimbursement from the estate if it were held personally liable for

When Ross contended that the order to turn over stock certificates to the receiver would deprive him of his right against self-incrimination under the fifth amendment, the Second Circuit specifically declined to apply the Daniels case or to decide at that time whether Ross could properly claim the fifth amendment privilege with respect to corporate books and records of the foreign corporations not doing business in the United States. Id. at 834-35.

105. In Daniels, the court was impressed by the fact that petitioner was the president and sole stockholder of his corporation, that the corporation did no business in the United States and that the Service addressed its summons to the petitioner in his individual capacity rather than as a representative of his corporation. $140 \mathrm{~F}$. Supp. at 327-28.

106. See text accompanying note 54 sipra.

107. In the Montreal Trust Company case, the bank argued in the district court that the New York long-arm statute could only be tused to stue on a cause of action which arose directly from and was immediately related to business done in the state. The bank argued that the claim for income tax was not a claim "arising from" the decedent's alleged acts in the jurisdiction within the meaning of the statute. The court refused to accept such a narrow view of the statute, 35 F.R.D. at 221-22.

108. INT. REv. CODE of 1954, \& 6901 . 
the estate's tax obligations. This would simply be an application of the idea expressed in Daniels that the Service may not do indirectly what it is barred from doing directly. Indeed, similar reasoning could be used to limit the statute providing for transferee liability where the transferee could prove that the assets of the estate were unreachable and that no cause of action for reimbursement from the estate could be maintained in the foreign court. ${ }^{109}$

That the scope of Code provisions in the international area may depend on foreign law is not heretical; the principle is well illustrated by established rules regarding service of a subpoena on a foreign fiduciary. If the subpoena is validly served in the United States, the fiduciary will have to comply, even to the point of producing records kept outside of the United States. ${ }^{110}$ But an exception to this rule is recognized where to do so would violate the law of the country where the fiduciary resides. In Application of Chase Manhattan Bank, ${ }^{111}$ a grand jury subpoena duces tecum directed Chase to produce records held at its branch in the Republic of Panama. Chase agreed to produce all relevant records in its possession in New York, but refused to produce records from its Panama branch unless it was shown that the production of such records did not violate Panamanian law. The bank's concern was the possibility that it would be committing a crime under the law of Panama if it acceded to the requests of the Service. When during the course of the hearings, the government of Panama enacted a law which prohibited the reproduction of certain books for use in an action abroad in compliance with the orders of foreign authorities, the court modified the Service's subpoena to exclude the demand for such materials. ${ }^{112}$

The real difficulty with giving the Service every opportunity to obtain jurisdiction by which it may attempt to compel the payment of taxes by a foreign fiduciary is that this approach does not adequately account for the real dilemma in which the foreign fiduciary may find himself. The Service has

109. The liability of transferees is several, and normally a transferree may be held liable for the full amount of tax up to the value of the assets received by him. Phillips v. Commissioner, 283 U.S. 589, 603 (1931). Nonetheless, it is assumed that a transferee who has paid more than his proportionate share of the tax has a right to contribution against other transferees and a right of reimbursement from the estate. See PhillipsJones Corp. v. Parmley, 302 U.S. 233, 237 (1937).

110. The principle that jurisdiction once obtained brings with it the power to direct action in foreign countries is well set forth in SEC v. Minas de Artemisa, 150 F.2d 215 (9th Cir. 1945). See also In re National Pub. Util. Corp., 79 F.2d 302 (2d Cir. 1935); In re Rivera, 79 F. Supp. 510 (S.D.N.Y. 1948).

111. 297 F.2d 611 (2d Cir. 1962). Accord, First Nat'l City Bank v. IRS, 271 F.2d 616 (2d Cir, 1959), cert. denied, 361 U.S. 948 (1960) (subpoena duces tecum reinstated where there was no showing that law of Panama would be violated by compliance). See also, Note, Limitations on the Federal Judicial Power to Compel Acts Violating Foreign Law, 63 ColvMr. L. Rev. 1441 (1963) ; Note, Subpoenta of Documents Located in Foreign Jurisdiction Where Law of Situs Prohibits Removal, 37 N.X.U.I. REv. 295 (1962).

112. 297 F.2d at 613 . The facts of the decision indicate that the grand jury instructed Chase to produce the Panamanian records on January 30,1961, and that on the same day the President of Panama signed into law the legislation prohibiting production of the records. $I d$. at 612 . The transcript of the testimony of the expert witness produced by Chase indicates that the legislation restricting removal of records from Panama had been introduced some time before. Joint Appendix to Record at $62 \mathrm{a}$. 
shown that it may not be ready to exercise the necessary self-restraint. ${ }^{113}$ If an international tax collection case involving a foreign fiduciary of a foreign asset estate is pressed unfairly on an administrative or a judicial level, the decision will profoundly affect the position of our citizens abroad and the position of this country in the international community. At best, the United States can expect foreign countries to treat our citizens no better than we treat foreigners. It is certainly in this country's interest to encourage foreign fiduciaries, particularly corporate fiduciaries, to invest in the United States and to deal with American companies abroad, as well as to continue to have faith in our system of justice. It does not seem enough to voice the hope, as the Supreme Court did in Omar, ${ }^{114}$ that in the event matters get out of hand, the executive branch will step in.

\section{The Foreign Fiduciary's Dilemma}

The reality of the foreign fiduciary's dilemma is well illustrated by a review of the facts presented in an unreported decision of the Supreme Court of Ontario. 115

Harron, a Canadian citizen and domiciliary, created an irrevocable lifetime trust naming the Toronto General Trusts Corporation (now by merger the Canada Permanent Trust Company) as trustee. Under the terms of the trust, income was payable to the settlor during his life, remainder as the settlor might appoint. In default of any appointment on the settlor's death, income was payable to his wife for life, remainder to Toronto General Hospital. Common stock of a United States corporation comprised the corpus of the trust. Harron died in California in 1954, and his wife became the recipient of the income of the trust until her death in 1957. OIO requested the trustee to file an estate tax return but it declined to do so. The executor of Harron's estate, who was also contacted by OIO, did file a return. In 1961, both the executor and the trustee were assessed for payment of estate taxes due. Apparently,

113. See 297 F.2d at 612. During the proceedings against the bank, the Service learned that it could gain access to Panamanian records of American firms by making application directly through the Panamanian courts. Joint Appendix to Record at 55a. But only after subjecting the bank to lengthy court proceedings did the Service (after being denied access to the books and records through the American courts) turn to the Panamanian courts and ultimately gain its objective. Letter from James P. Power, Ass't Staff Counsel, The Chase Manhattan Bank, to author, Oct. 16, 196\%. Considering the presence of such an alternative way in which to proceed, it can be questioned whether the Service should have continued to press its case against Chase after it had learned that it could move in a foreign court. Similarly, Omar can be viewed as a case in which the Service pressed for a temporary injunction at a time when there was no foreseeable way for it ultimately to collect on a judgment.

114. 379 U.S. at $384-85$.

115. In re Farron (Ont. Sup. Ct., June 23, 1965) (unreported decision). The facts of the Harron case are reported on the basis of an affidavit submitted to the court by an officer of the trust company who served as trustee. Record at 3-9. Copies of documents referring to the Harron case are on file at the library of the University of Connecticut School of Law. 
the theory behind OIO's assessment of the trustee was its personal liability as a transferee.

Following the assessment, the trustee proceeded to make inquiry into the scope of its liability. Its counsel in the United States rendered an opinion that:

(a) the tax levied by the United States Treasury Department has been properly assessed;

(b) in the case of a non-resident of the United States, no deduction is allowed under the U.S. Internal Revenue Code for the value of property passing to a charitable institution which is not a United States organization;

(c) all parties concerned, namely the Executor, the Trustee and the Hospital, are personally liable for the tax, and the assets owned by each of them and located in the United States can be levied upon for payment;

(d) criminal penalties enforceable in the United States are imposed upon any person who wilfully fails to pay the tax and these would apply to a person taking part in a decision not to pay.116

Canadian counsel for the trustee then learned from the OIO that it was preparing upwards of thirty notices of levy against various banks, trust companies, investment dealers and other financial institutions in New York City who were indebted to the trustee. ${ }^{117}$ OIO did not suggest that it would hold off on its collection efforts until the trustee could gain instructions from the Canadian court. Indeed, OIO clearly indicated to counsel for the trustees that its policy was to continue all possible efforts to collect the tax by seizures, levies and the like and that whenever possible the scope and number of such efforts would be expanded and increased. 118 In particular, it was stressed that an attempt would be made to serve notices of levy against the American Express Company, various United States banks and bond paying agencies, and other similar agencies so that the trustee would be prevented from obtaining recovery or reimbursement in connection with United States obligations which might become due to it in the course of its ordinary business. ${ }^{119}$

Apparently OIO made it quite clear that its intention was to tie up completely the trustee's personal affairs in the United States as soon as possible. Indeed, in two cases where notices of levy were served, the assets or accounts levied upon were in fact held by the trustee in trust or as agent for some other person or corporation, and in order to satisfy the United States authorities that this was in fact the case, the trustee found it necessary to prepare or obtain and submit extensive and precise documentation of the terms of the trusts or agencies in question. ${ }^{120}$ These procedures required many hours of time on

116. Record at 5-6. The hospital's position is outlined in detail in its counsel's brief to the court. Brief for Respondent, the Trustees of the Toronto General Hospital.

117. Record at 6-7.

118. Id. at 7.

119. Id.

120. Id. at 7-8. 
the part of the trustee and caused it expense, trouble, embarrassment and disruption in the carrying on of its personal business. ${ }^{121}$ Apparently, OIO made no advance investigation to avoid the occurrence. Nor did OIO suggest a plan under which the trustee would be given time to obtain an adjudication from the Canadian court on its rights and obligations. Understandably, after OIO's actions, the trustee was happy to cooperate with the Service.

When so informed, the Hospital-beneficiary set out to investigate the situation. It was informed by its legal counsel that the relevant general rule of conflict of laws is that courts will not recognize foreign revenue laws in proceedings which in substance are an attempt to enforce indirectly a claim to tax by the revenue authorities of another state. ${ }^{122}$ Counsel took the position that difficulties encountered by the trustee in the United States as a result of the Service's efforts at collection did not involve the administration of the trust, and that since the Hospital could not benefit from the payment of the taxes due, the use of the trust fund for the payment of such taxes would be in breach of the trustee's fiduciary duty. ${ }^{123}$ Accordingly, the Hospital refused to authorize the trustee to indemnify itself out of the trust assets for any United States tax which the trustee might pay and would not recognize any right in the trustee to do so. ${ }^{124}$

The trustee then requested direction from the Supreme Court of Ontario on the following questions:

1. Is the Trustee entitled to be indemnified out of the trust property for any monies which it may pay in respect of the claim of the Internal Revenue Service of the United States Treasury Department for United States federal estate taxes, penalties and interest assessed and outstanding against the Trustee?

2. Has the Trustee any right or obligation to assert a claim over against the executor of the will and trustee of the estate of the deceased Settlor for reimbursement in respect of any monies so paid, and if so, to what extent ?125

Without comment, the court held in the affirmative as to the first question. As to the second question, it held that the trustee had a right to reimbursement for taxes which it might pay but was under no obligation to assert it against the trust or the estate. ${ }^{126}$

The decision of the Supreme Court of Ontario was subject to appeal to the Court of Appeal for Ontario and ultimately to the Supreme Court of Canada; however, a settlement was reached with OIO.

In the Harron case, the lower Canadian court may have been willing indirectly to help the United States enforce its tax judgment because it was

121. $I d$.

122. Brief for Respondent, The Trustees of the Toronto General Hospital, at 3.

123. Id. at 4 .

124. Record at 9.

125. Id. at 1 .

126. In re Harron (Ont. Sup. Ct., June 23, 1965) (unreported decision). 
impressed with the unfairness of a situation which allowed OIO to threaten the trustee's carrying on business in the United States and to place it in a position where its personal assets could be levied upon although it might not have a right to reimbursement from the estate. In light of the general policy that foreign tax judgments will not be enforced, what the final result would have been had the case been appealed is a matter of conjecture. The Harron decision may forecast the result in a number of cases arising in foreign countries in which beneficiaries who are not subject to the jurisdiction of the United States will refuse to grant fiduciaries of foreign-asset estates permission to satisfy United States taxes, citing basic tenets of international law. Assuming the fiduciary is denied reimbursement by the foreign court, if a fiduciary were held to personal liability by the Service, the fiduciary might have no right of recourse against the estate. And it has been seen that thus far the Service cannot be relied upon voluntarily to refrain from pressing persorial liability claims against a fiduciary until it is shown that the fiduciary is entitled to reimbursement from the estate under foreign law. Regardless of countless statements made by the Commissioner of Internal Revenue as to the importance of large questions of tax policy over the collection of revenue, ${ }^{127}$ the Service has not yet demonstrated restraint in exercising its international tax collecting powers against foreign fiduciaries.

\section{A Proposal,}

Judicial approval of the use of the New York long-arm statute against nonresidents in tax cases means that the Service now has a new and potent device to obtain increased jurisdiction over foreign fiduciaries, basing such jurisdiction on the business transacted by the decedent, or his agents, in the United States during his life. A twofold problem results from this development.

It is not clear that it is wise for the Service to have its newly attained power. International tax collection is a most delicate matter. ${ }^{128}$ The Service's record to date does not insure that it will distingnish a foreign fiduciary who is faced with a real dilemma from the nonresident taxpayer who is merely attempting to evade paying taxes. ${ }^{129} \mathrm{~A}$ keener awareness by OIO and foreign fiduciaries of foreign asset estates of the unique problems involved in tax collection may alleviate this problem. If so, it does not make sense to tie the Service's expanded powers against nonresidents to state long-arm statutes. Employing state long-arm statutes will mean a clear absence of uniformity.

127. See, e.g., Cohen, New IRS Philosophy, Trial, Aug./Sept. 1967, at 58; Cohen, Current Developments in the Chief Counsel's Office, 42 TAxes 663 (1964).

128. See text accompanying note 114 stepra.

129. Cf. Commissioner v. Lester, 366 U.S. 299 (1961). Justice Douglas, concurring, states: "Resort to litigation rather than to Congress, for a change in the law is too often the temptation of government which has a longer purse and more endurance than any taxpayer." Id. at 307 . 
The long-arm statute in each state (if there is one at all) will be worded differently from others and be subject to the varying interpretations of state courts. ${ }^{130}$ The policies and constitutional problems underlying the interpretation of the statutory language will vary as between domestic problems and international problems-state problems and purely federal problems. Due process requirements in international tax collection-will not always be equivalent with the due process requirements imposed on the states. ${ }^{131}$ The draftsmen of long-arm statutes never intended to have them applicable in the area of international tax collection, and the statutes are not drawn with this end in mind. Indeed, it is not entirely clear that the draftsmen of amended Rule 4 of the Federal Rules of Civil Procedure intended to allow the use of state long-arm statutes in such cases.

A Federal long-arm type statute specifically designed to gain jurisdiction for the Service abroad is the necessary response. So long as there is a reasonable basis for imposing tax on an individual, his acts in the United States or even his mere failure to file tax returns in the United States during his life could be support for jurisdiction over his estate at death. The draftsmen of a federal statute might also consider the desirability of attempting to gain personal jurisdiction over a foreign fiduciary on its act of administering the estate in the United States, or even an its mere failure to file tax returns and pay the taxes owed by the estate in the United States. Whether it would be constitutional to say that such inaction on the part of a foreign fiduciary constituted a sufficient contact with the United States for jurisdictional purposes under a federal statute appears to be an open question. But the statute could be designed to provide relief to the fiduciary by granting it the apportunity to seek instructions from the foreign court. If the foreign court determined that foreigu law prevented the fiduciary from paying taxes to the United States, such a decision rendered by the highest foreign court of the country could absolve the fiduciary of any tax obligation. Perhaps OIO could bear the costs involved in such litigation. If the estate were found free from liability to the United States by the foreign court, a transferee subject to United States jurisdiction should be liable for only a pro rata share of the taxes due if he can show that under foreign law he would be denied reimbursement from the estate.

Considering Congress' recent willingness to legislate to expand the power

130. See Feathers v. McLucas, 15 N.Y.2d 443, 461-62, 209 N.E.2d 68, 77-78, 261 N.Y.S.2d 8, 21-22, cert. denied, 382 U.S. 905 (1965). In 1966 section 302 was amended to overturn this case which interpreted subdivision (a) (2) of CPLR 302 as providing in personam jurisdiction over non-domiciliaries only when a tortious act was committed within the state.

131. Cf. United States v. First Nat'l City Bank, 379 U.S. 378 (1965). Justice Harlan, dissenting, termed the possibility that the New York court would interpret CPLR $\S 302(a)$ to give personal jurisdiction over Omar, who merely traded long distance for his own account on the New York exchanges, a "glib assumption." Id. at 391-92. 
to tax under the Expatriation Act $^{132}$ so as to bring within the taxing framework former Americans who divest themselves of citizenship to escape tax, Congress should be sympathetic to legislation which would implement the collection of taxes due from abroad and at the same time foster good relations with other nations.

132. INT. Rev. CoDe of 1954, §§ 877, 2107. 